\title{
Dogs and echinococcosis in Iceland
}

\author{
Sigurdur Sigurdarson \\ From Parasite infections of domestic animals in the Nordic countries - emerging threats and challenges. \\ The 22nd Symposium of the Nordic Committee for Veterinary Scientific Cooperation (NKVet) \\ Helsinki, Finland. 7-9 September 2008
}

\section{History}

Hydatid disease was first described in Icelandic literature about the year 1200. According to the first qualified physician in Iceland, Bjarni Pálsson (1719-1779) was echinococcosis about 1760 one of the most frequent diseases among the human population, and was also commonly observed in sheep and cattle. Autopsies and questionaries indicate that $20-25 \%$ of the inhabitants might have been infested by hydatidosis about 1850 . The nature of the disease was still unknown at that time. The dog population was estimated to be $15.000-$ 20.000 , or about one dog for every three or four people. At the same time there were in Copenhagen 1 dog for every 30-32 persons. Obviously there were too many dogs in Iceland. The sheep, cattle, dogs and humans lived in close contact. The dogs often shared a room and even bed with the family, and were the best playmate for the children. The people lived mostly in primitive houses at that time and under primitive hygienic conditions. It is therefore not wonder that the hydatid disease flourished as long as the nature of the disease was still obscure.

In 1849 the Danish physician P.A.Schleisner (18191900) concluded that one out of every six Icelanders suffered from hydatid disease. In 1862 doctor Harald Krabbe (1831-1917) from the Royal Veterinary and Agricultural University in Copenhagen studied the hydatid problem in Iceland. He found that 28 out of 100 dogs and most of the old sheep and cows that were slaughtered were infested with echinococcus cysts. Experiments he carried out in cooperation with an Icelandic physician Jón C Finsen (1826-1885) proved the relationship between taenias in dogs and the hydatid cysts in humans. Doctor H. Krabbe realized that most important was to inform the people of the nature of the

The Icelandic Food- and Vetarinary Authority Austurvegur 64, 800 Selfoss, Iceland disease in order to prevent the infestations of humans and animals with eggs of the intestinal parasites of the dog. H. Krabbe was a chief adviser to the Icelandic government on hydatid disease and prophylactic measures in the period 1860-1890. His recommendations were followed strictly for more than 100 years and partially they still are. New infestations by E. granulosus practially dissappeared in Iceland the decade 1890-1900. That is based on 7333 autopsies of people performed in the period 1932-1966. And based on 15.888 autopsies 19321982 only few human infestations occurred after 1900 . The most recent human cases are a person born in 1937 who was autopsied in 1960, another person born in 1905 operated 1984 and the third person born in 1920 operated in 1988. In 1863 an autopsy survey of 100 dogs were carried out. E. granulosus was found in 28 of them, 75 dogs carried T. marginata. In the period one hundred years later 200 dogs were autopsied (19501960). T. marginata was found in 11 dogs but none of them carried E. granulosus. Reports of meat inspectors from Icelandic abattoirs did not record hydatid cysts in cattle, pigs and horses after 1961. However in the period 1953-1979, cysts of echinococcus were recorded in a total of 21 old ewes, all of which came from few farms on 2 small areas in East-Iceland. There was an indication that the parasite had been introduced to the country by an imported dog. After 1979 no hydatid cysts have been found in any animal in Iceland.

\section{Why so successful control of hydatid disease in Iceland}

Echinococcosis is a great public health and economic problem in many countries. It has been extremely difficult to eliminate it in many endemic areas. Apparently it was done in Iceland rather easily. How?

The campaign against hydatid disease in Iceland was for more than one century and partially still is based on Harald Krabbe's recommendations: 1) Succesful information to the people. Most people in Iceland had lost 
either relatives or friends as a victim to hydatid disease and the memory of this disease was and still is dreaded. When people knew what to do, strong parcipitation of both young and old was easy to activate.

2) Reduction of the dog population by taxes on all dogs, higher tax on unnessesary dogs and a ban on keeping a dog without permission. Outbrakes of distemper in 1870, 1888 and 1890 reduced the number of dogs considerably, 3)Preventing the dog gaining access to raw offal and burning cysts in organs 4) Caution in dealing with dogs, esp. Children, 5) Yearly anthelmintic treatment of all dogs after the slaughtering sesion. Some factors that assisted in the campaign: -Ceasing of milking sheep on the farms, - improvement of the houses and hygiene, -strictly practiced caution on the contact between dogs and animals/people. Building of slaughterhouses all over the country in the period 19001920, then slaughtering on the farms almost ceased. The hydatid disese was never found in horses, rodents or in wild animals in Iceland.

Published: 13 October 2010

\section{References}

1. Pálsson PA: Echinococcosis and its elimination in Iceland. In a book in regi of Ivan Kati'c Köbenhavn Harald Krabbe Dagbog fra Island 2000, 93-100, Ferðasaga(1863, 1870, 1871).

2. Pórarinsdóttir KH: Echinokokkosen i Island og dr. Harald Krabbes indsats for dens bekæmpelse. Köbenhavn OSVAL II - opgave, Köbenhavns University, medicinske fakultet 1999.

3. Dungal N: New Zealand medical journal. 1957, 56:212-222.

4. Einarson M: Búnaðarrit. 1901, 15:125-164.

5. Einarson M: Dýralækningabók. Reykjavík 1931, 91-93, 232-235.

6. Finsen J: lagtagelser angaaende Sygdomsforholdene I Island. Köbenhavn 1874,177

7. Hliðar Sig E: Lækning húsdýra Akureyri. 1915, 66-68, 102-104

8. Jónassen J: Ekinokoksygdommen belyst ved islandske Lægers Erfaring. Köbenhavn 1882, 268.

9. Jónsson V: Skírnir. 1954, 128:134-175

10. Jónsson S: Tidsskrift for Veterinærer. 1879, 137-178, 2. Rk., 9 Bd,.

11. Krabbe $\mathrm{H}$ : Athugasemdir handa Íslendingum um sullaveikina og varnir móti henni. Köbenhavn 1864, 18.

12. Krabbe H: Helmintologiske Undersögelser I Danmark og paa Island med særlig hensyn til Blæreormlidelserne paa Island. Köbenhavn 1865, 64.

13. Magnússon G: Yfirlit um sögu sullaveiki á Íslandi. Reykjavík 1913, 83.

14. Pálsson PA, Vigfússon H, Henriksen K: Læknablaðið. 1971, 57:39-51.

15. Sigurðsson J: Nordisk Medicinhistorisk Årsbog. 1970, 182-198.

16. Thoroddsen P: Landbúnaður á Íslandi. 1922, 2:73-84.

17. Bang B: Biografier af lærere ved De Danske Veterinærskole. Medlemsblad for Den Danske Dyrlægeforening, 6. Aargang, Köbenhavn 1923, 93-99.

18. Schultz Forlag JH: Dansk Biografisk Leksikon.. Bnd. 13 Köbenhavn 1938

19. Dungal N: Er sullaveikin að hverfa á Íslandi? Læknablaðið 1942, 28:121-128.

20. Dungal N: Eradication of Hydatid Disease in Iceland. New Zealand Medical Journal 1957, 56:212-222

21. Eschricht D: Afhandling om de Hydatider, der fremkaldte den I Island endemiske leversyge. l: Oversigt over Videnskabernes Selskabs Forhandlinger 1857, 211-239.

22. Faust EC: Echinococcus Disease. Nelson Loose-Leaf Medicine // New York, 1 1920, 433.

23. Fenger E: Plan til en Forelæsnings-Cyclus. Kbh 1843

24. Fridriksson G: Saga Reykjavíkur 1870-1940. Reykjavik: Iðunn 1994

25. Garcia LS, Bruckner DA: Diagnostic medical parasitology. 1997.
26. Jónasson J: Íslenskir pjóðhættir. 3 utg Reykjavík: Ísafoldarprentsmiðja 1961.

27. Jónsson V: Sullaveikirannsóknir Jóns Finsen og Haralds Krabbe. Skírnir 1954, 128:134-175

28. Krabbe H: Om Echinokokkerne, I. del I: Ugeskrift for Læger. Række 2 1862, 37(15):225-235.

29. Krabb H: Om Echinokokkerne, II. del. I: Ugeskrift for Læger. 2 Række 1862, 37(16):241-259.

30. Krabbe H: Echinokokksygdommen på Island. Ugeskrift for læger 1864, 41(1):1-19, 2. Række.

31. Krabbe H: Blæreormlidelserne på Island og de imod dem trufne Foranstaltninger. Tidsskrift for Veterinærer 1865, 20:205-222, 2. Række.

32. Krabbe H: Helmintologiske Undersögelser I Danmark og paa Island med særlig hensyn til Blæreormlidelserne paa Island. 1: Det Kongelige Danske Videnskabernes Selskabs Skrifter 5. Række, naturvidenskabelig og mathematisk Afdeling 1865, 7:347-408, Köbenhavn, 64 pp.

33. Leared A: Athugasemdir um sullaveikina á Íslandi. Islendingur 1862 , 3:105-106

34. Leared A: Athugasemdir um sullaveikina á Íslandi. Pjóđólfur 1862, 15:33-34

35. Magnússon G: Yfirlit yfir sögu sullaveikinnar á Íslandi. Fylgirit Árbókar Háskóla Íslands fyrir háskólaárið 1912-1913. Reykjavík 1913.

36. Einarsson Matthías: Hvernig fær fólk sullaveiki? Læknablaðið 1925, 11:98-100.

37. Nielsen JB: Parasitologi - et kompendium. Köbenhavn: FADL's Forlag, 2 1994.

38. Olafsens og Povelsens Reise gennem Island. Soröe 1772.

39. Pálsson PA, Vigfússon H, Henriksen K: Læknablaðið. 1971, 57:39-51.

40. Pálsson PA: Echinococcosis and its elimination in Iceland. Hist Med Vet 1976, 1:4-10

41. Pálsson PA: Echinococcosis in Iceland - historical review. XVII. Interrnational Congress of Hydatology, Limassol, Cyprus, nov. 6-10 1996.

42. Pétursson J: Lækningabók fyrir Almúga. Köbenhavn: Udg. Af Thorsteinn Jónsson 1834.

43. Roberts L, Janovy J: Foundations of Parasitology. Boston: Wm.C. Brown Publishers, 51996

44. Schleisner PA: Island undersögt fra et lægavidenskabeligt Synspunkt. Köbenhavn: Boghandler C.G.Iversen 1849.

45. Sun T, Rackson M, Farber B: Current status of Hydatid Disease. Digestive Diseases 1988, 6:170-184

46. Thorsteinsson B, Jónsson B: Íslandssaga til okkar daga. Reykjavík: Sögufélag 1991

doi:10.1186/1751-0147-52-S1-S6

Cite this article as: Sigurdarson: Dogs and echinococcosis in Iceland.

Acta Veterinaria Scandinavica 2010 52(Suppl 1):S6.

\section{Submit your next manuscript to BioMed Central and take full advantage of:}

- Convenient online submission

- Thorough peer review

- No space constraints or color figure charges

- Immediate publication on acceptance

- Inclusion in PubMed, CAS, Scopus and Google Scholar

- Research which is freely available for redistribution 